\title{
Characterization of Two Families of Spontaneously Amplifiable Units of DNA in Streptomyces ambofaciens
}

\author{
By PHILIPPE DEMUYTER, * PIERRE LEBLOND, BERNARD DECARIS \\ AND JEAN-MARC SIMONET \\ Laboratoire de Génétique et Microbiologie, Faculté des Sciences, Université de Nancy I, BP 239, \\ Boulevard des Aiguillettes, 54506 Vandoeuvre les Nancy, France
}

(Received 29 December 1987; revised 7 March 1988)

\begin{abstract}
Four highly amplified DNA sequences (ADS) ranging from 5.8 to $24.8 \mathrm{~kb}$ were found in spontaneous mutant strains of Streptomyces ambofaciens DSM 40697. Restriction patterns of total DNA were hybridized with purified ADS6 $(24.8 \mathrm{~kb})$ as a probe to detect the amplifiable regions in the wild-type (WT) genome. The results suggested that the amplifiable unit of DNA (AUD) was present as a single copy in the WT genome. Moreover, similarities suggested by the restriction maps of three of the ADS were confirmed by hybridization experiments. The fourth ADS did not hybridize with the three others. Therefore, two families of DNA sequences are potentially amplifiable in the $S$. ambofaciens genome.
\end{abstract}

\section{INTRODUCTION}

Streptomycetes often exhibit a high degree of genetic instability. Many characters have been reported to be unstable, for example antibiotic resistance (Freeman et al., 1977; Hütter et al., 1981; Altenbüchner \& Cullum, 1984), pigment synthesis (Suter et al., 1978; Schrempf, 1983), and aerial mycelium formation (Usdin et al., 1985). The frequency of mutant colonies after treatments such as UV light exposure (Freeman \& Hopwood, 1978), cold storage (Suter et al., 1978 ) or growth in the presence of ethidium bromide or acridine orange (Suter et al., 1978; Hütter et al., 1981) reaches $10 \%$ or higher. Genetic instability could be due to plasmid loss (Hara et al., 1983; Usdin et al., 1985) or to chromosomal instability by formation of large deletions including the unstable gene (Hintermann et al., 1984, 1985; Usdin et al., 1985; Flett \& Cullum, 1987). In the latter case, no reversion could be observed. In addition, highly reiterated DNA sequences are commonly observed in Streptomyces DNA associated with deletions (Ono et al., 1982; Altenbüchner \& Cullum, 1985; Hasegawa et al., 1985; Dyson \& Schrempf, 1987). Moreover, highly reiterated stretches have been detected after ethidium bromide treatments (Schrempf, 1982, 1983; Ono et al., 1982; Hasegawa et al., 1985), interspecific protoplast fusion (Robinson et al., 1981), selection for overexpression of the spectinomycin-resistance gene (Hornemann et al., 1987), protoplasting and regenerating (Fishman \& Hershberger, 1983), or spontaneously (Altenbüchner \& Cullum, 1984; Baltz \& Stonesifer, 1985).

The work reported here concerns Streptomyces ambofaciens DSM 40697, a spiramycin producer. Preliminary observations showed that this strain exhibits a high frequency $(0.9 \%)$ of spontaneous pigment-negative mutant colonies. Highly reiterated DNA sequences were detected and characterized in spontaneous mutant strains of $S$. ambofaciens. These investigations led to the identification of two DNA regions in the $S$. ambofaciens genome which are susceptible of a high degree of amplification.

Abbreviations: ADS, amplified DNA sequence(s); AUD, amplifiable unit of DNA; WT, wild-type. 


\section{METHODS}

Strains. The wild-type (WT) Streptomyces ambofaciens DSM 40697 strain was used. Mutant strains isolated from it are described in Results.

Media and culture conditions. Streptomyces strains were grown at $37^{\circ} \mathrm{C}$ on plates of Hickey Tresner medium (Hopwood et al., 1982). Before DNA extraction, the Streptomyces cultures were grown aerobically at $37^{\circ} \mathrm{C}$ in YEME liquid medium supplemented with glycine (0.25\%) for $48 \mathrm{~h}$ (Hopwood et al., 1982).

DNA extraction. The mycelium was harvested by centrifugation, resuspended in TE buffer (Tris/ $\mathrm{HCl} 10 \mathrm{mM}$, EDTA $1 \mathrm{mM}, \mathrm{pH} 8.0$ ) and mixed with lysozyme (Boehringer Mannheim) $\left(2 \mathrm{mg} \mathrm{ml}^{-1}\right)$. Protoplasts were formed by incubation of the mixture at $30^{\circ} \mathrm{C}$ for $30 \mathrm{~min}$ and lysed with sodium dodecyl sulphate (SDS) (1\%) in the presence of proteinase $\mathrm{K}\left(50 \mu \mathrm{g} \mathrm{ml}^{-1}\right)$. DNA was purified by two phenol/chloroform extractions followed by one chloroform extraction. The aqueous phase was treated with ribonuclease $\mathrm{A}$ (Sigma) $\left(5 \mathrm{mg} \mathrm{ml}^{-1}\right)$ for $1 \mathrm{~h}$ at $37^{\circ} \mathrm{C}$. DNA was precipitated with sodium acetate $(0 \cdot 3 \mathrm{M}, \mathrm{pH} 5 \cdot 2)$ and 2-propanol at $-20^{\circ} \mathrm{C}$. After centrifugation, the pellet was vacuum-dried and dissolved in TE buffer. DNA was purified by equilibrium density centrifugation in $\mathrm{CsCl} /$ ethidium bromide gradients, using a vTi 65.2 rotor (Beckman) at 65000 r.p.m. for $6 \mathrm{~h}(400000 \mathrm{~g})$.

Restriction endonuclease digestion analysis. Restriction enzymes were purchased from Appligène or Boehringer Mannheim and used as recommended by the suppliers. DNA fragments were electrophoresed on $0 \cdot 6 \%$ agarose gels according to Maniatis et al. (1982). Bacteriophage $\lambda$ DNA digested by HindIII was used as size standard.

Isolation of DNA fragments. Restriction fragments to be used for the nick-translation step were purified from agarose gels by electro-elution followed by chromatography on commercially available columns (Schleicher and Schüll) or by the Geneclean process (Bio 101).

Nick-translation, prehybridization, hybridization and autoradiography. DNA fragments were ${ }^{32} \mathrm{P}-$ labelled by nicktranslation (Rigby et al., 1977) using [ $\left.{ }^{32} \mathrm{P}\right] \mathrm{dCTP}$ and a nick-translation kit (Amersham). For hybridization experiments, DNA fragments were electrophoresed on agarose gels, and blotted on Hybond- $\mathrm{N}$ membranes (Amersham) according to Southern (1975). DNA fragments were covalently linked to the membrane by exposure to UV light for $5 \mathrm{~min}$.

Prehybridization and hybridization solutions consisted of formamide $50 \%(\mathrm{v} / \mathrm{v})$, Ficoll $0 \cdot 1 \%$, bovine serum albumin $0.1 \%$, polyvinylpyrolidone $0.1 \%$, denatured salmon sperm DNA $200 \mu \mathrm{g} \mathrm{ml}^{-1}, 6 \times$ SSC $(1 \times$ $\mathrm{SSC}=0.15 \mathrm{M}$-sodium chloride, $0.015 \mathrm{M}$-sodium citrate), $0.5 \% \mathrm{SDS}$. After blotting, the nylon membrane was incubated for $4 \mathrm{~h}$ at $42^{\circ} \mathrm{C}$ in a sealed plastic bag containing the prehybridization mixture. The hybridization mixture, consisting of prehybridization solution containing ${ }^{32}$ P-labelled probe $\left(7 \times 10^{7}\right.$ d.p.m. $\left.\mu \mathrm{g}^{-1}\right)$, was added and the bag was further incubated overnight at $42{ }^{\circ} \mathrm{C}$. The nylon membrane was then removed, washed with $2 \times$ SSC, $0.1 \%$ SDS at room temperature for $1 \mathrm{~h}$ (one change of washing solution), then washed with $0.1 \times \mathrm{SSC}, 0 \cdot 1 \%$ SDS at $50^{\circ} \mathrm{C}$ for $2 \mathrm{~h}$ (with three changes of washing solution) and finally rinsed twice with $0.1 \times \mathrm{SSC}, 0 \cdot 1 \% \mathrm{SDS}$ and four times with $0.1 \times$ SSC. Autoradiographies were performed using Hyperfilm-MP (Amersham) with an intensifying screen. Films were exposed at room temperature for $6 \mathrm{~h}$ to $3 \mathrm{~d}$.

\section{RESULTS}

\section{Isolation of variant strains}

Genetic instability is revealed by the occurrence of spontaneous pigment-negative mutant colonies at high frequency. With the WT $S$. ambofaciens DSM 40697, $0.9 \%$ of colonies were pigment-negative and $7 \cdot 4 \%$ contained pigment-negative sectors. Mutant strain NSA101 was subcloned from a pigment-negative homogeneous clone (sector-free). Some pigment-negative colonies are affected by a reverse instability and give rise either to homogeneous WT colonies or to revertant sectors on mutant colonies. Mutant strain NSA103 was isolated from such a revertant sector.

A novel phenomenon arising from pigment-negative colonies and affecting numerous morphological characters, especially pigmentation, was the occurrence of progeny without any preponderant phenotype. The mutant strains exhibit highly variable pigmentation ranging from WT to pigment-negative phenotype. Mutant strains NSA6 and NSA102 were subcloned from such a progeny.

\section{Characterization of amplified DNA}

Strains NSA6, NSA101, NSA102 and NSA103 were characterized and compared to the WT by restriction analysis of total DNA (Fig. 1). This revealed intense bands which represent highly amplified DNA. The background pattern showed no detectable difference from the WT DNA, showing that the mutant strains are derived from S. ambofaciens DSM 40697. 


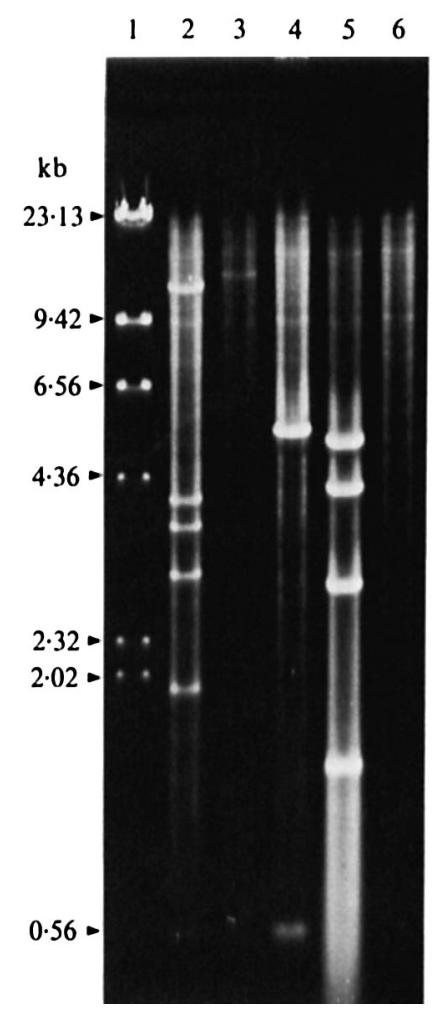

Fig. 1. Restriction patterns of total DNA from the WT and mutant strains of $S$. ambofaciens. DNA was digested with BamHI and electrophoresed on $0.6 \%$ agarose gel at $1 \mathrm{~V} \mathrm{~cm}^{-1}$ for $18 \mathrm{~h}$. Tracks: 1, 0.5 $\mu \mathrm{g}$ of $\lambda$ DNA digested with HindIII as size marker; $2,1.5 \mu \mathrm{g}$ of NSA6 DNA; $3,0.75 \mu \mathrm{g}$ of NSA101 DNA; 4 , $1 \mu \mathrm{g}$ of NSA102 DNA; $5,1 \mu \mathrm{g}$ of NSA103 DNA; $6,1 \mu \mathrm{g}$ of WT DNA.

Undigested DNA of the mutant strains showed no detectable extrachromosomal bands on agarose gels (data not shown). In addition, no covalently closed circular DNA was observed in equilibrium density centrifugation on $\mathrm{CsCl}$ gradients, so the amplifications were not present in this form.

In each strain, the total size of the amplified DNA deduced by digestion with different enzymes was about the same. Hence the amplified fragments are contiguously organized in amplified DNA sequences (ADS). The sizes calculated from compilation of the single and double digestions, and the restriction maps of the four ADS, are shown in Fig. 2(a,b). ADS6, ADS101 and ADS102 show high similarities, while ADS103 is very different from the three others. All the known cleavage sites of ADS101 and ADS102 are recovered in ADS6. It was not possible to deduce from the restriction maps whether ADS101 and ADS102 overlapped. The restriction maps indicate that there are two families of ADS represented: the first family includes ADS6, ADS101 and ADS102, the second family is represented by ADS103.

Assuming a genome size of $4.9 \times 10^{3} \mathrm{~kb}$ (Genthner et al., 1985), and according to the amount of DNA in the slots, the relative fluorescence of the intense bands in the agarose gel permitted an estimate of the proportion of amplified DNA in each mutant strain (NSA6, 20\%; NSA101, $5-10 \%$; NSA102, $20 \%$; NSA103, $50 \%$ ) and of the number of copies of the ADS (ADS6, 50 copies; ADS101, 20 copies; ADS102 and ADS103, 200 copies).

\section{Hybridization between reiterated sequences}

Strain NSA6, containing the largest ADS $(24.8 \mathrm{~kb})$ was chosen to provide the DNA probe. DNA of strain NSA6 was digested with $X$ hoI plus $P$ st I to generate three predominant fragments 
(a)

ADS103: $12 \cdot 8 \mathrm{~kb}$

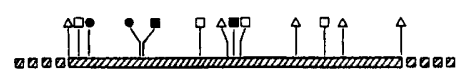

(b)

ADS6: $24.8 \mathrm{~kb}$

ADS101: $17.0 \mathrm{~kb}$

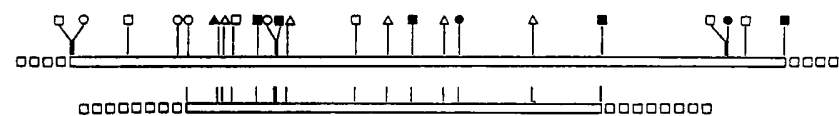

ADS102: $5.8 \mathrm{~kb}$ $5 \mathrm{~kb}$

(c)

WT DNA

AUD6

AUD101

AUD102

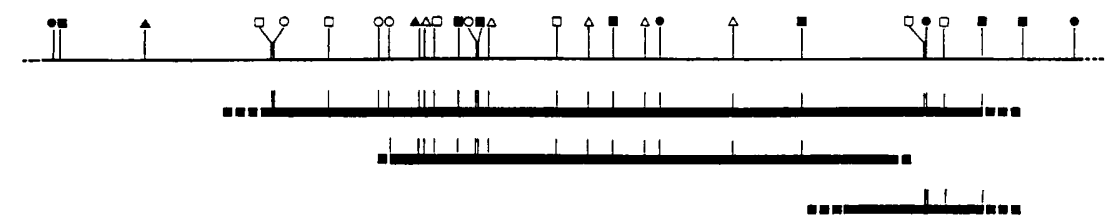

Fig. 2. Restriction maps of the two families of ADS in mutant strains of $S$. ambofaciens. (a) ADS in NSA103 ('ADS103 family'). (b) ADS in NSA6, NSA101, NSA102 ('ADS6 family'). (c) Amplifiable units of DNA (AUD) and identification of flanking sequences based on hybridization experiments. Symbols used for cleavage sites: $\square, B a m \mathrm{HI} ; \square, B c l \mathrm{I} ; \mathrm{O}, B g l \mathrm{II} ; \boldsymbol{O}, P s t \mathrm{I} ; \triangle, P v u \mathrm{II} ; \Delta, X h o \mathrm{I}$. The dotted lines represent unknown areas.

$(7 \cdot 8,8.4$ and $8.6 \mathrm{~kb})$. After electrophoresis, these fragments were eluted, purified and labelled by nick-translation. However, it was essential to control the presence of DNA of the same size which could comigrate with eluted DNA. These fragments cleaved again with BamHI were therefore used as target in a hybridization test (Fig. $3 a$, track 2). The hybridization pattern (Fig. $3 b$, track 2) is characteristic of ADS6, including the faint bands generated by partial digestion. The background due to the presence of contaminating DNA allows an estimation of the quality of the probe: it was suitable to detect a $1.3 \mathrm{~kb}$ single homologous sequence in the WT DNA digested with $B c l$ I as shown in further results (Fig. 4, track 3). In the hybridization test performed on DNA of NSA6, all typical DNA stretches are observed (Fig. $3 b$, track 3 ).

Southern blots of NSA101, NSA102, NSA103 and WT DNA digested with PvuII or BamHI were hybridized with the ADS6 probe (Fig. $3 b$, tracks 4, 5, 6 and 7). All typical reiterated DNA stretches of ADS101 and ADS102 were detected as heavy bands (Fig. $3 b$, tracks 4 and 5). Under the same hybridization conditions, no intense signals were detected with BamHI digests of NSA103 and WT DNA (Fig. $3 b$, tracks 6 and 7). Longer exposure of these latter autoradiographs revealed typical ADS6 sequences, with the exception that one fragment $(2.9 \mathrm{~kb})$ was absent and two additional fragments $(13$ and $17 \mathrm{~kb})$ were found. This experiment shows that a DNA sequence homologous with ADS6 is present in DNA of both the WT and NSA103. This homologous DNA sequence corresponds to the amplifiable unit of DNA (AUD6). In addition, the two bands of 13 and $17 \mathrm{~kb}$ correspond to hybridization with flanking sequences of the AUD. The $2.9 \mathrm{~kb}$ fragment is generated by tandem reiteration of the AUD.

The fact that DNA of NSA103 and the WT shows the same hybridization pattern with the ADS6 probe suggests that the DNA of NSA103 can be considered as identical to the WT DNA with respect to ADS6.

Southern blots of NSA101 DNA digested with various restriction enzymes were probed with a $B c l$ digest of ADS102 (5.8 kb fragment) (data not shown). The results confirmed an overlap between ADS101 and ADS102.

\section{Restriction map of AUD region}

Southern blots of various digests of WT DNA were hybridized with the ADS6 probe to allow the restriction mapping of AUD6 and its flanking DNA (Fig. 2c). These results proved that AUD6 is present as a single copy: most particularly, $X$ hol digestion generated only two flanking 


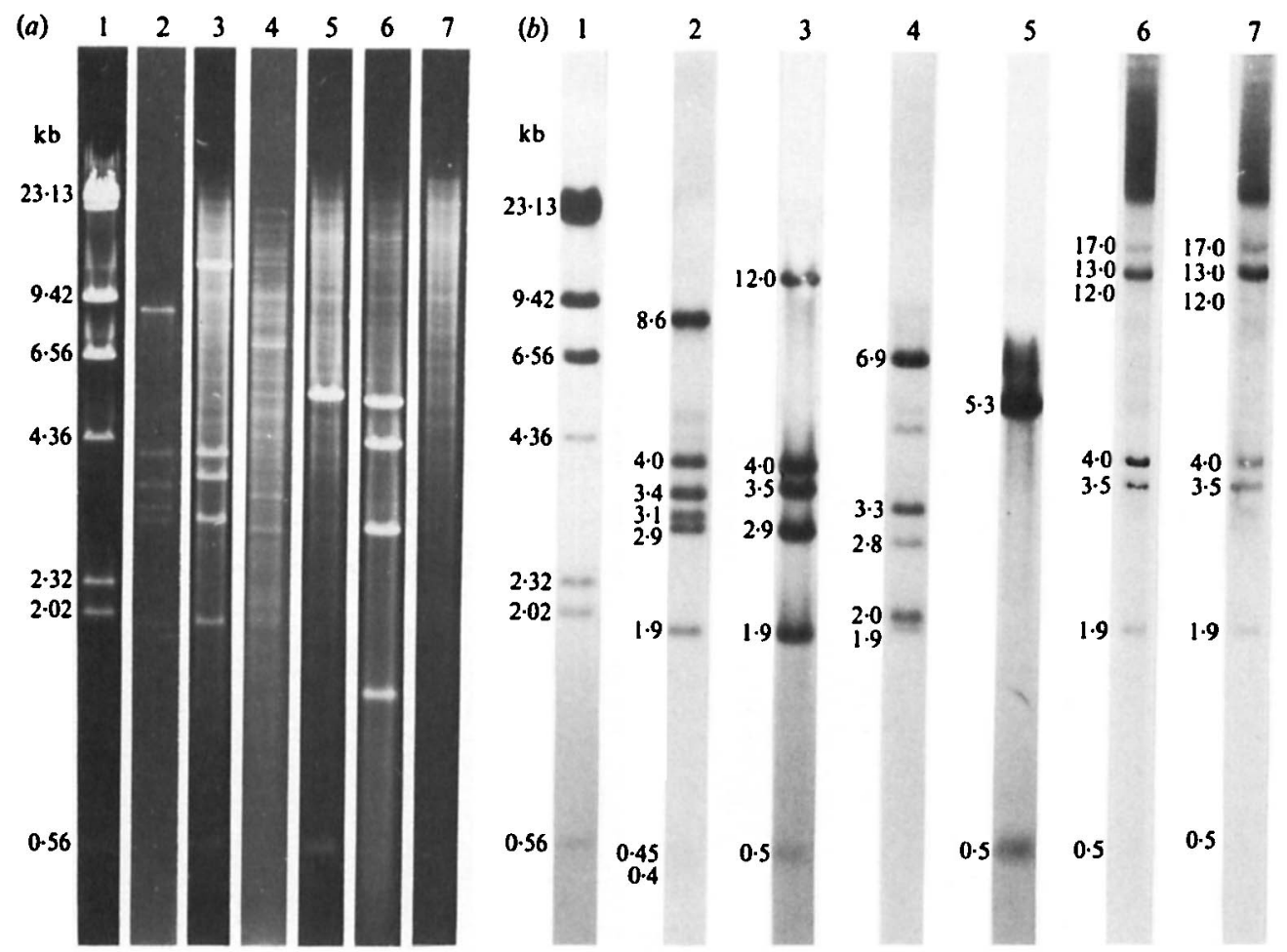

Fig. 3. Hybridization of ${ }^{32} \mathrm{P}$-labelled ADS6 DNA with digests of DNA from mutant and WT strains. (a) Agarose gel separation of total DNA prepared from the WT and from mutant strains with amplified DNA. (b) Southern blot hybridization. Tracks: 1 , HindIII-digested $\lambda$ DNA; 2, eluted ADS6 DNA triple digested with $X$ hoI/PstI/BamHI; 3, NSA6 total DNA digested with BamHI; 4, NSA101 total DNA digested with PvuII; 5, NSA102 total DNA digested with BamHI; 6, NSA103 total DNA digested with BamHI; 7, WT DNA digested with BamHI. Restriction enzyme digestions, agarose gel electrophoresis, nick-translation and membrane hybridization were done as described in Methods (electrophoretic conditions: $1 \mathrm{~V} \mathrm{~cm}^{-1}$ for $18 \mathrm{~h}, 0.6 \%$ agarose). Autoradiograph exposure times: tracks 1,3 and 5 for $4 \mathrm{~h}$, tracks 2 and 4 for $7 \mathrm{~h}$, tracks 6 and 7 for $60 \mathrm{~h}$.

sequences (Fig. 4, track 7). This confirmed that the AUD is not duplicated in the WT genome.

Accordingly, two 'families' of AUD are characterized in the WT DNA: the 'AUD6 family', which includes AUD6, AUD101, AUD102, and the 'AUD103 family', represented by the ADS103.

\section{DISCUSSION}

This work reports the identification of at least two 'families' of amplifiable units of DNA in $S$. ambofaciens DSM 40697. Analogous results related to overlapping reiterated sequences were reported for the Streptomyces glaucescens genome after mutagenic treatments (Hasegawa et al., 1985). However, possible rearrangements associated with DNA amplification have not yet been investigated in our $S$. ambofaciens mutant strains.

The accuracy of the AUD restriction map does not reveal any long direct repeats as in other Streptomyces species (Altenbüchner \& Cullum, 1985; Fishman et al., 1985; Hornemann et al., 1987). A model based on homologous recombination between direct repeats of the AUD during the replication has been proposed for DNA amplification in Streptomyces lividans 66 (Young \& Cullum, 1987). However, this model seems unlikely in $S$. ambofaciens, since although a duplicated, pre-amplified AUD was detected in the WT strain S. lividans 66 (Dyson \& Schrempf, 1987), AUD6 is present as only a single copy in the WT $S$. ambofaciens genome.

The genomic location of the AUD and ADS is not yet known. A location as stable 


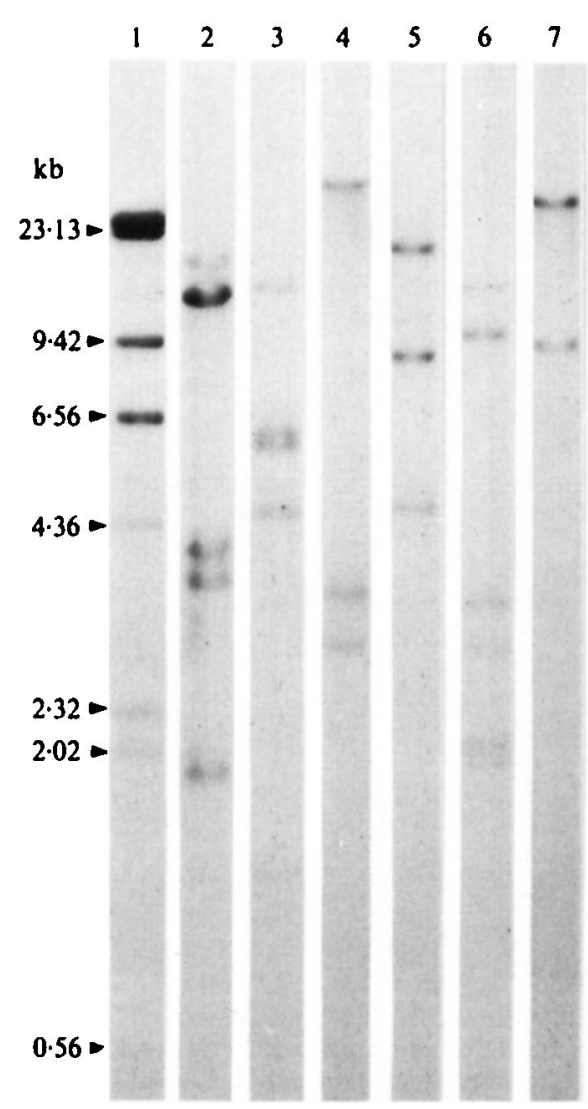

Fig. 4. Hybridization of ${ }^{32}$ P-labelled ADS6 DNA with total WT DNA digested with a range of restriction enzymes. Tracks: 1 , HindIII-digested $\lambda$ DNA ; $2, B a m \mathrm{HI} ; 3, B c I I$; 4, BglII ; 5, PstI ; 6, PvuII ; 7, XhoI.

extrachromosomal DNA undetectable by classical methods remains possible. Stable amplified DNA in drug-resistant Leishmania has been reported as large extrachromosomal circles (Garvey \& Santi, 1986), and giant plasmids $(410-560 \mathrm{~kb})$ have recently been characterized in Streptomyces coelicolor A3(2) (Kinashi et al., 1987).

Additional information about the structure and location of the AUD and ADS are essential for an understanding of the phenomenon of amplification and its relationships with genetic instability.

We acknowledge the financial support provided by Ministère de la Recherche et de l'Enseignement Supérieur, by CNRS, and by Université de Nancy I.

\section{REFERENCES}

Altenbüchner, J. \& CUllum, J. (1984). DNA amplification and an unstable arginine gene in Streptomyces lividans 66. Molecular and General Genetics 195, 134-138.

Altendǘchner, J. \& CUllum, J. (1985). Structure of an amplifiable DNA sequence in Streptomyces lividans 66. Molecular and General Genetics 201, 192197.

BaltZ, H. R. \& Stonesifer, J. (1985). Phenotypic changes associated with loss of expression of tylosin biosynthesis and resistance genes in Streptomyces fradiae. Journal of Antibiotics 38, 1226-1236.
DYSON, P. \& SCHREMPF, H. (1987). Genetic instability and DNA amplification in Streptomyces lividans 66. Journal of Bacteriology 169, 4796-4803.

Fishman, S. E. \& Hershberger, C. L. (1983). Amplified DNA in Streptomyces fradiae. Journal of Bacteriology 155, 459-466.

Fishman, S. E., Rosteck, P. R. \& Hershberger, C. L. (1985). A 2-2-kilobase repeated DNA segment is associated with DNA amplification in Streptomyces fradiae. Journal of Bacteriology 161, 199-206.

Flett, F. \& Cullum, J. (1987). DNA deletions in spontaneous chloramphenicol-sensitive mutants of 
Streptomyces coelicolor A3(2) and Streptomyces lividans 66. Molecular and General Genetics 207, 499502.

FreEMAN, R. F. \& Hopwood, D. A. (1978). Unstable naturally occurring resistance to antibiotics in Streptomyces. Journal of General Microbiology 106, 377-381.

Freeman, R. F., BibB, M. J. \& Hopwood, D. A. (1977). Chloramphenicol acetyltransferase-independent chloramphenicol resistance in Streptomyces coelicolor A3(2). Journal of General Microbiology 98, 453465.

GaRVEY, E. P. \& SANTI, D. V. (1986). Stable amplified DNA in drug-resistant Leishmania exists as extrachromosomal circles. Science 233, 535-540.

GeNTHNER, F. J., HoOK, L. A. \& STROHL, W. R. (1985). Determination of the molecular mass of bacterial genomic DNA and plasmid copy number by highpressure liquid chromatography. Applied and Environmental Microbiology 50, 1007-1013.

hara, O., Horinouchi, S., Uozumi, T. \& Beppu, T. (1983). Genetic analysis of A-factor synthesis in Streptomyces coelicolor A3(2) and Streptomyces griseus. Journal of General Microbiology 129, 2939-2944.

Hasegawa, M., Hintermann, G., Simonet, J. M., Crameri, R., Piret, J. \& HÜtter, R. (1985). Certain chromosomal regions in Streptomyces glaucescens tend to carry amplifications and deletions. Molecular and General Genetics 200, 375-384.

Hintermann, G., Crameri, R., Vogtli, M. \& HütTER, R. (1984). Streptomycin-sensitivity in Streptomyces glaucescens is due to deletions comprising the structural gene coding for a specific phosphotransferase. Molecular and General Genetics 196, 513-520.

HintermanN, G., ZatChes, M. \& HÜtTER, R. (1985) Cloning and expression of the genetically unstable tyrosinase structural gene from Streptomyces glaucescens. Molecular and General Genetics 200, 422-432.

Hopwood, D. A., BibB, M. J., Chater, K. F., Kieser, T., BRUTON, C. J., KIESER, H. M., LydiATE, D. J., Smith, C. P., Ward, J. M. \& SchrempF, H. (1982). Genetic Manipulation of Streptomyces. A Laboratory Manual. Norwich: The John Innes Foundation.

HornemanN, H., Otto, C. J., Hoffman, G. G. \& BERTINUSON, A. C. (1987). Spectinomycin resistance and associated DNA amplification in Streptomyces achromogenes subsp. rubradiris. Journal of Bacteriology 169, 2360-2366.

HÜTTER, R., KIESER, T., CRAMERI, R. \& HintermanN, G. (1981). Chromosomal instability in Streptomyces glaucescens. Zentralblatt für Bakteriologie, Mikrobiologie und Hygiene (supplement) 11, 551-559.
KINASHI, H., ShImaJI, M. \& SaKaI, A. (1987). Giant linear plasmids in Streptomyces which code for antibiotic biosynthesis genes. Nature, London 328 , 454-456.

Maniatis, T., Fritsch, E. F. \& Sambrook, J. (1982). Molecular Cloning: a Laboratory Manual. Cold Spring Harbor, NY: Cold Spring Harbor Laboratory.

Ono, H., Hintermann, G., Crameri, R., Wallis, G. \& HÜTTER, R. (1982). Reiterated DNA sequence in a mutant strain of Streptomyces glaucescens and cloning of the sequence in Escherichia coli. Molecular and General Genetics 186, 106-110.

Rigby, P. W. J., DieckmanN, M., Rhodes, C. \& BeRg, P. (1977). Labelling deoxyribonucleic acid to high specific activity in vitro by nick translation with DNA polymerase I. Journal of Molecular Biology 113, 237-251.

Robinson, M., Lewis, E. \& Napier, E. (1981). Occurrence of reiterated DNA sequences in strains of Streptomyces produced by an interspecific protoplast fusion. Molecular and General Genetics 182, 336-340.

SCHREMPF, H. (1982). Plasmid loss and changes within the chromosomal DNA of Streptomyces reticuli. Journal of Bacteriology 151, 701-707.

SCHREMPF, H. (1983). Deletion and amplification of DNA sequences in melanin-negative variants of Streptomyces reticuli. Molecular and General Genetics 189, 501-505.

SOUTHERN, E. M. (1975). Detection of specific sequences among DNA fragments separated by gel electrophoresis. Journal of Molecular Biology 98, 503-517.

SUTER, M., HÜTTER, R. \& LeISINGER, T. (1978). Mutants of Streptomyces glaucescens affected in the production of extracellular enzymes. In Genetics of Actinomycetales, pp. 61-64. Edited by E. Freerksen, I. Tarnok \& J. H. Thumin. Stuttgart \& New York: Gustav Fischer.

Usdin, K., Christians, K. M., De Wet, C. A., Potgieter, T. D., Shaw, C. B. \& Kirby, R. (1985). The loss of a large DNA fragment is associated with an aerial mycelium negative $\left(\mathrm{Amy}^{-}\right)$phenotype of Streptomyces cattleya. Journal of General Microbiology 131, 979-981.

Young, M. \& Cullum, J. (1987). A plausible mechanism for large scale chromosomal DNA amplification in Streptomyces. FEBS Letters 212, 10 14. 